\title{
DISTRIBUTION OF THE LICHEN SPECIES CETRARIA ACULEATA IN HUNGARY
}

\author{
M. SINIGLA ${ }^{1}$, L. LÖKÖS ${ }^{2}$, N. VARGA ${ }^{3}$ and E. FARKAS ${ }^{3}$ \\ ${ }^{1}$ Bakony Museum of the Hungarian Natural History Museum \\ H-8420 Zirc, Rákóczi tér 3-5. Hungary; sinigla@nhmus.hu \\ ${ }^{2}$ Department of Botany, Hungarian Natural History Museum \\ H-1476 Budapest, Pf. 222. Hungary; lokos@bot.nhmus.hu \\ ${ }^{3}$ Institute of Ecology and Botany, Centre for Ecological Research, Hungarian Academy of Sciences \\ H-2163 Vácrátót, Alkotmány u.2-4. Hungary; farkas.edit@okologia.mta.hu
}

\begin{abstract}
Cetraria aculeata became legally protected in Hungary in 2005. Though for several decades it was known from a few localities only, recently it turned out that it is more frequent than previously ascertained. However, its range of distribution is insufficiently known and the species is still regarded to be rare. The present assessment is based on its specimens from Hungary; the currently known data of occurrences are presented on an updated distribution map. The recent records from the Bakony Mts (Királyszentistván, Sóly), Mecsek Mts (Cserkút, Pécs) and the Velence Mts (Pázmánd) are new to Hungary, and the one from the Gödöllő Hills (Erdőkertes) turned to be a recent confirmation of Boros' old record (1962) at Vácegres locality.
\end{abstract}

Key words: Cetraria aculeata, legally protected, lichen-forming fungi

\section{INTRODUCTION}

Cetraria aculeata (Schreb.) Fr. is a terricolous, fruticose lichen species, rare in Hungary. It is a typical vagrant species, its branches forming spherical thalli that are transported by wind or animals relatively easily in open areas (Fig. 1). Earlier it was treated under three other generic names (Cetraria, Cornicularia, Coelocaulon) by various authors (BOROS 1963, KäRNEFELT 1986, KÁRPÁTI and Kárpáti 1954a, $b$, Köfaragó-Gyelnik 1937, Précsényi and Opauszky 1979, Verseghy 1975, 1994); its specimens from Hungary were identified as either Cornicularia aculeata (Schreb.) Ach. or C. steppae Savicz, and its identity with C. muricata (Ach.) Ach. was also considered (J. Poelt, A. Vězda, pers. comm.). VerSEGHY (1975) mistakenly identified this lichen as C. steppae by microcrystal test.

When discussing related genera in his monograph, KäRNEFELT (1986) carried out detailed investigations on the secondary chemistry of this species. According to his TLC analysis of some Hungarian samples (Vácrátót: Tece, 1986), their identity with C. aculeata was confirmed. This result was also supported by our recent HPTLC studies on specimens from additional localities. In 
recent papers published world-wide, the species is studied from various aspects (Domaschke et al. 2012, 2013, FernÁNDEZ-Mendoza et al. 2011, GielwaNOWSKa and Olech 2012, Nadyeina et al. 2013, PÉrez-Ortega et al. 2012).

According to previous literature sources only two populations were known in Hungary (VerSEghy 1975, 1994): 1. Göd-Vác-Vácegres-Vácrátót region (as Cornicularia steppae), 2. Velence Mts (as Cornicularia aculeata/tenuissima). This was the reason why it was included in the Hungarian lichen red list proposal as a critically endangered species (Löкӧs and Tóтн 1997). In 2005 Cetraria aculeata was suggested for legal protection on the basis of its extreme rarity within Hungary. For the proposal of its conservation, all herbarium and literature records were considered (FARKAS and LöKös 2004, 2005, 2006, 2007). As a result of the detailed documentation and justification, C. aculeata has become legally protected in 2005 (MK 2005, 2008, 2013). Fostering a deeper knowledge of the Hungarian populations became necessary for conservation purposes, therefore

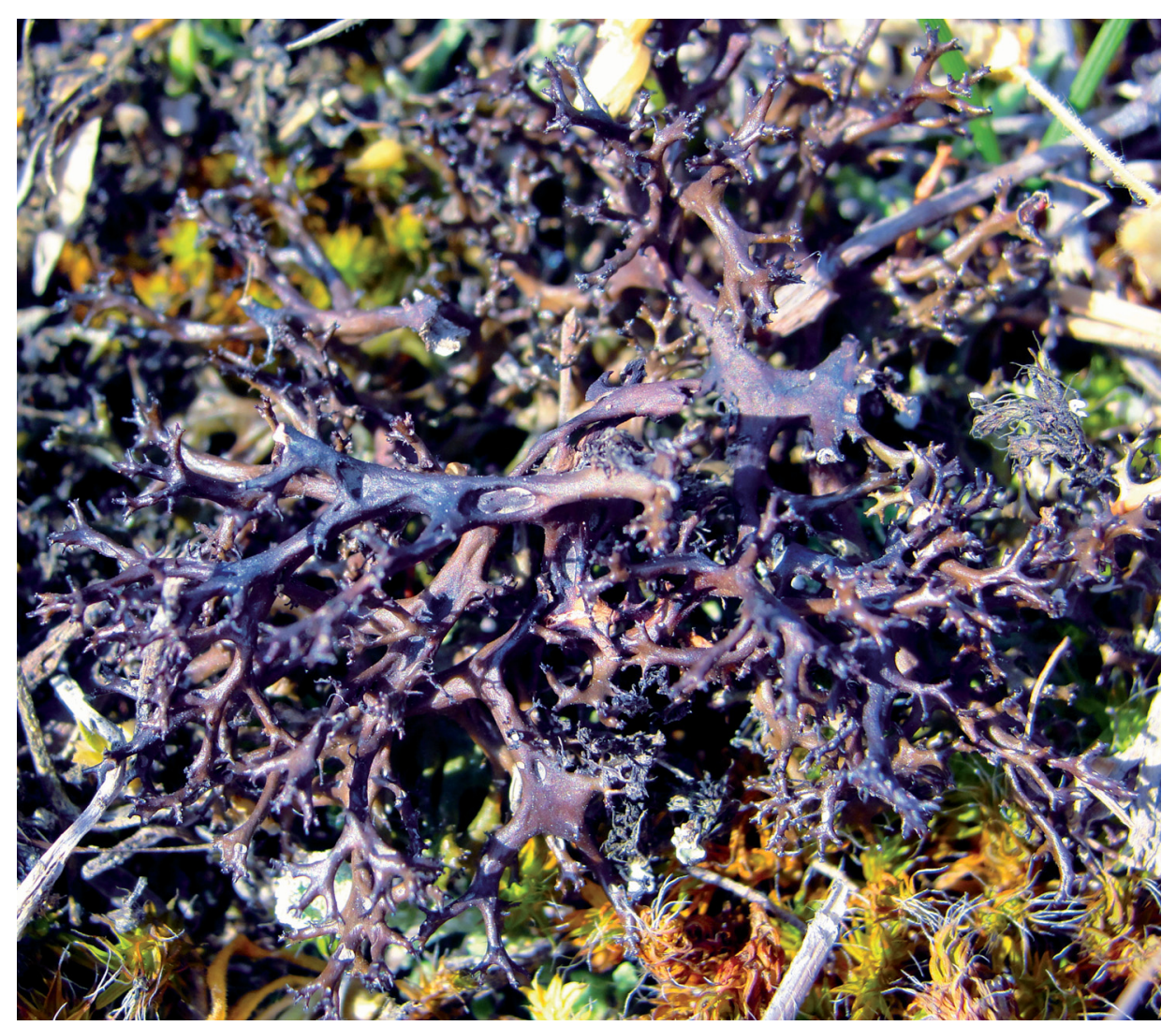

Fig. 1. General habit of Cetraria aculeata. 
we decided to revisit the earlier localities and search for possibly new ones with the prospect that we can produce a more accurate range map of the species. The results, encompassing the old and new records and observations on its habitat conditions, are hereby presented.

\section{MATERIAL AND METHODS}

Specimens were studied in Hungarian herbaria (BP, EGR, JPU, SZE, VBI), fresh collections (after 2005) were deposited in herbaria BP, BTM and VBI (abbreviations mainly follow the Index Herbariorum online; THIERs 2014).

For the distribution map (Fig. 2) a computer program for geographic information system (QGIS 2.6 Brighton, 2014) was applied where grid cells follow the Central European mapping system (cf. NI KLFELD 1971). Since 2005, the locality data have been measured by Garmin Etrex Vista C GPS (WGS84).

Detailed morphological characterisation and a preliminary distribution map were provided by FARKAS and LöKös (2007).

\section{RESULTS AND DISCUSSION}

With 12 localities, approximately 60 specimens of $C$. aculeata are found in historical collections of the Hungarian lichen herbaria (recorded under various

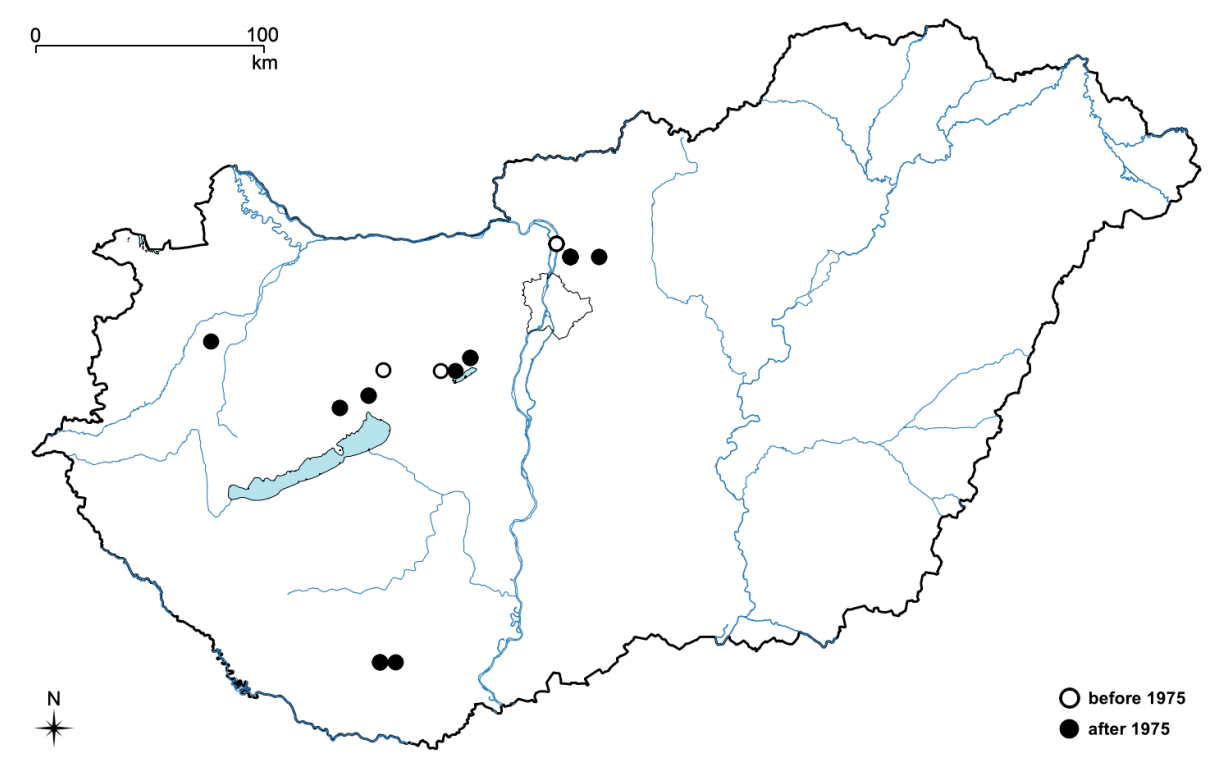

Fig. 2. Localities of Cetraria aculeata in Hungary. 
names, i.e. Cetraria aculeata, Coelocaulon aculeatum, Cornicularia aculeata, Cornicularia odontella, Cornicularia steppae, Cornicularia tenuissima). Most of the collecting sites are located in the Göd-Vác-Vácegres-Vácrátót region, concentrating on the sand dune area in the surroundings of Szöd. The first specimen was collected by György Timkó at "Katonai gyakorlótér" at Vác in 1912 (FHE 1914, Tim Kó 1925). Most of the localities (4) were discovered by Ádám Boros (Boros 1918, 1920, 1949, 1962). Records from the Velence Mts were reported by Gábor Fekete (FEKETE 1954, 1956).

In the 1980s our attempt to revisit these earlier known localities was largely without success. Its best known locality in "Tece" protected area at Vácrátót was checked from time to time, where its presence was continuous, but fires (the largest one in 2005) and occasional motocross activities led to its decrease and these hazards still pose a real threat to this population. Since precise details of the locality on older herbarium labels were usually absent, our efforts to locate its occurrences at Öskü and in the Velence Mts were unsuccessful. Most of the old localities were destroyed or totally altered, e.g., "Katonai gyakorlótér" at Vác, or Csekély-hegy (= Cseket-hegy) in the Velence Mts.

After our publication (FARKAS and LöKös 2007) came out, several new localities were discovered in recent years: four in the Bakony Mts/Balaton-felvidék (Királyszentistván: Ugri-hegy, Litér: Mogyorós-hegy; Veszprém: Tekeres-völgy; Sóly), two from the Mecsek Mts (Cserkút; Pécs: Sülevölgy), one each from the Vasi-Hegyhát area (Ostffyasszonyfa: farakodó) and one from the Velence Mts (Pázmánd: Zsidó-hegy). Among these populations two are of considerable size - at Cserkút and Ugri-hegy, while the other localities are characterised by rather scattered/sporadical occurrence only. The population at Vácegres was revisited several times and finally it was located (today the site belongs to Erdökertes: Háromház, Erdőkertesi-homokpuszta). The size and vitality of this population is really good, the conditions at this habitat seem to be even better than the other nearby population (Vácrátót: Tece). In contrary to the fading hopes with extinctions in former habitats, the discovery of previously unknown localities raises some hope for the survival of C. aculeata in Hungary.

Cetraria aculeata is characterised by a rather wide ecological amplitude throughout its distributional range in Europe. In the boreal temperate regions the most typical habitats are ocean-influenced, either basic or acidic heathlands (with Calluna vulgaris, Deschampsia flexuosa, Festuca ovina, Corynephorus canescens, Aira praecox), and it also occurs in less disturbed coastal sand dune areas dominated by Carex arenaria or Ammophila arenaria. In southern Europe it is found in various types of calcareous steppes (KäRNEFELT 1986). The Hungarian occurrences are located in either calcareous or acidophilous sandy or rocky grasslands (Figs 3A-B). Very few information on its habitat preferences is available 

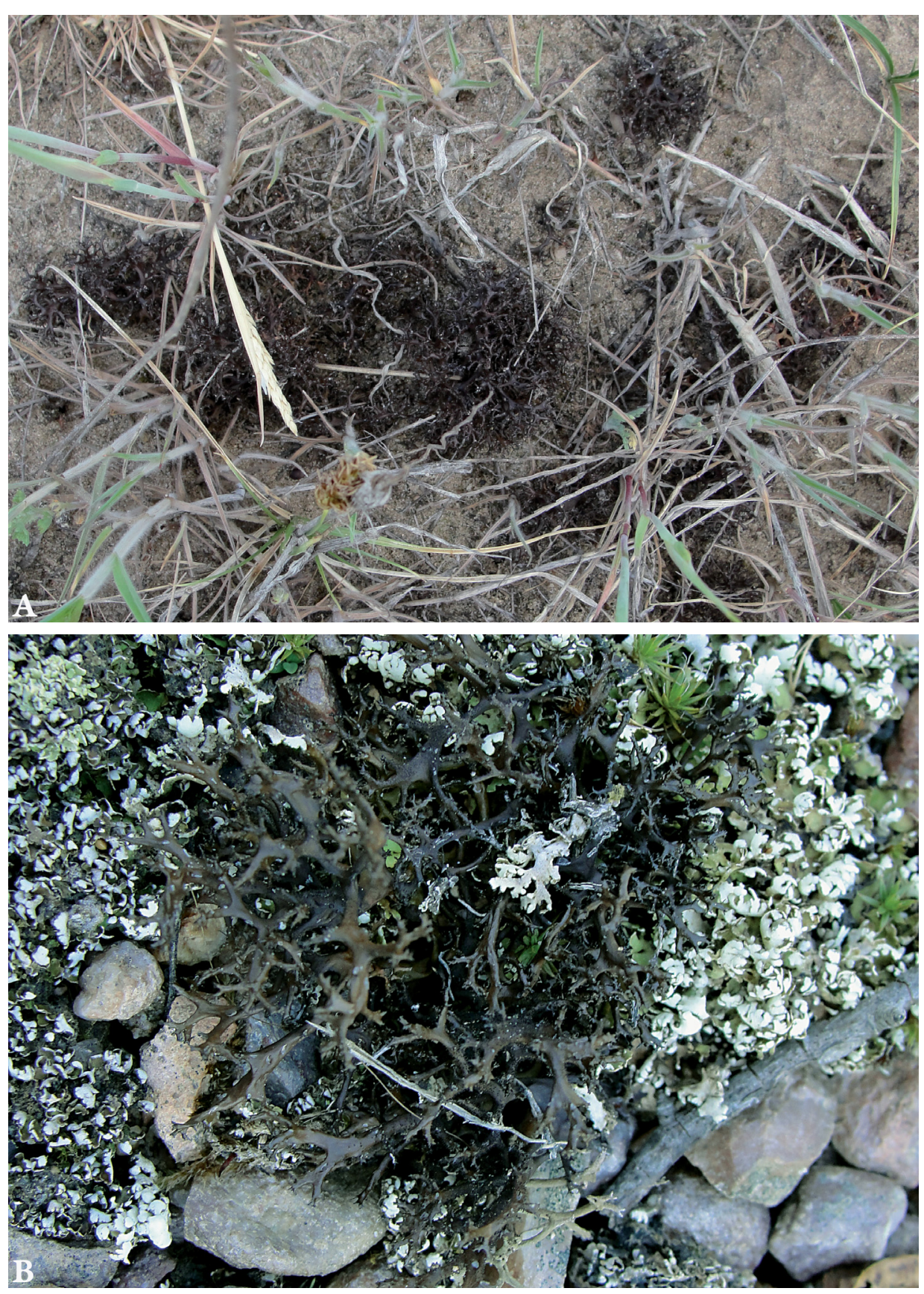

Fig. 3. Cetraria aculeata in open, calcareous, sandy habitat together with grasses (A), and together with other lichens on acidic rocky grassland (B). 
in the Hungarian phytosociological literature. A detailed survey on the periodical aspects of the calcareous sandy grassland association (Festucetum vaginatae danubiale) was carried out in the environs of Vácrátót in 1952 (KÁRPÁTI and KÁRPÁTI 1954a, b). Although Cetraria aculeata was included in this study among other terricolous lichens in the Lichenes-Bryophyta aspect (Cladonia-Syntrichia phase), the aspect values were analysed only for higher plants. Occurring in habitats with semi-desert characters Cetraria aculeata was considered by ZóLYOMI $(1958,1987)$ as a member of the Fulgensio-Psoro-Toninion synusium growing especially in the degraded forms of the association Festucetum vaginatae danubiale. Cetraria aculeata was also mentioned from the plant association class KoelerioCorynephoretea (BORHIDI 2003, BorHidi et al. 2012), but no exact Hungarian locality data or ecological considerations were given. It is still rather difficult to explain why it is totally absent from its potential habitats, i.e. from calcareous sandy grassland associations in the areas of the Great Hungarian Plain or the Small Hungarian Plain. The ecological requirements and the life strategy of this species, as well as the environmental conditions of its habitat in Hungary are still not clearly understood. These should be further studied so that its potential habitats could be explored with a greater chance of probability. In addition, implementing investigations on the species' population dynamics would be important, useful and necessary for effective conservation.

\section{Hungarian locality records of Cetraria aculeata}

(Fig. 2)

The original label text is cited in the following enumeration. Literature sources related to the specimens, if they exist, are given in square brackets.

Bakony Mts - Litér (Veszprém megye): W side of hill Mogyorós-hegy, among bryophytes in open rocky grassland area. Alt.: 190-200 m a. s. 1. Coll.: Lőkös, L., Lőkös, D. and Farkas, E., 14.11.1998. (BP 94491, VBI) [FARKAS and LöKÖs 2007, FARKAS et al. 2014]. - Litér: Mogyoróshegy, mészkősziklagyepben. Lat.: $47^{\circ} 06^{\prime} 06.4^{\prime \prime} \mathrm{N}$, Long.: $18^{\circ} 01^{\prime} 21.2^{\prime \prime} \mathrm{E}$, Alt.: $220 \mathrm{~m}$ a. s. 1. Leg.: Farkas, E., Lőkös, L. and Şenkardeşler, A., 2006.11.11. (VBI) [FARKAS et al. 2014]. - Ad terram humosam inter muscos sub monte "Bérhegy" supra pag. Öskü, comit. Veszprém; alt. cca. $250 \mathrm{~m}$. Leg.: Timkó, Gy. (5237), 1926.05.21. (BP 91007). - Veszprém: Tekeres-völgy pereme, Sas-hegy, Vilmapuszta, mészkősziklagyepben. Leg.: Farkas, E. and Lőkös, L., 1993.06.22. (BP, VBI) [FARKAS and LöKös 2007]. - Veszprém: Tekeres-völgy pereme, Sas-hegy, Vilma-puszta, mészkősziklagyepben. Leg.: Farkas, E. and Lőkös, L., 199?. (BP, VBI) [FARKAS and Lökös 2007]. - Hungary. Veszprém County, Bakony Mts, Mt Sas-hegy, ca $4 \mathrm{~km} \mathrm{~W}$ of Veszprém, on the W-facing slope of valley "Tekeres-völgy" near Vilma-puszta, on calcareous soil in open rocky grassland. Lat.: $47^{\circ} 05^{\prime} 28.6^{\prime \prime} \mathrm{N}$, Long.: $17^{\circ}$ 51' 46.2” E, Alt.: ca 265 m a. s. 1. Coll.: Farkas, E. and Lőkös, L., 3 April, 2010. (BP 93943). - Comit. Veszprém, ad terram, in graminosis siccis (solo dolomitico), prope pag. Sóly. Alt. cca. 170 m s. m. Lat.: $47^{\circ} 08^{\prime} 11.38^{\prime \prime}$ N, Long.: $18^{\circ} 02^{\prime} 39.56^{\prime \prime}$ E. Coll.: Sinigla, M., 19.04.2013. (BTM Sóly/14). - Comit. Veszprém, ad terram, in graminosis siccis (solo dolomitico), in montis "Mogyorós-hegy", 
prope pag. Litér. Lat.: $47^{\circ} 06^{\prime} 06.72$ ” N, Long: 1801' 24.73” E, Alt. cca. $227 \mathrm{~m}$ s. m. Leg.: Sinigla, M., 04.09.2013. (BTM L/2) [FARKAS et al. 2014]. - Comit. Veszprém, ad terram, in graminosis siccis (solo dolomitico), in montis “Ugri-hegy”, prope pag. Királyszentistván. Lat.: $47^{\circ} 06^{\prime} 0.41$ ” N, Long: $18^{\circ} 02^{\prime} 13.05^{\prime}$ E, Alt. cca. 175 m s. m. Leg.: Sinigla, M., 04.09.2013. (BTM Ksz/5, BP 94570) [FARKAS et al. 2014].

Duna mente, Vác-Göd-Vácegres region - In herbidis arenosis territorii “Katonai gyakorlótér" infra oppidum Vácz, comit. Pest. Altit. ca. 110 m. Leg.: Timkó, Gy., 1912.03.22. (BP 25429 sub Cetraria aculeata var. campestris f. odontula) [Тімко́ 1925 sub Cetraria aculeata var. campestris, VERSEGHY 1994]. - In herbidis arenosis territorii "Katonai gyakorlótér" infra oppidum Vácz, comit. Pest. Altit. ca. 110 m. Mens. Mart. 1912. Leg.: Timkó, Gy. (BP 25421, BP 25422, BP 82015, BP 84576, EGR sub Cetraria aculeata f. campestris, SZE) [FHE 1914, VERSEGHY 1994, FARKAS and LöKös 2007]. - Hungaria. Homokbuckán füves, mohás helyen. Vác mellett a katonai gyakorlótéren. Leg.: Timkó, Gy., 1912.04.14. (BP 33591 sub Cornicularia steppae) [Verseghy 1994]. - Vácz, a Lőportorony és a Sződrákos puszta közti homokpusztán. Alt. s. m. met. ca. 100. Leg.: Boros, Á., 1918.03.30. (BP 45421, sub Cornicularia odontella, EGR) [Boros 1918]. - Comit. Pest, pr. opp. Vác, in pascuis. Leg. et don. dr. Ö. Szatala. (SZE). - Hungaria, Praematricum, in arenosis ad Szöd. Leg.: Degen, Á., 1920.03.21. (BP 25424, BP 45382, sub Cornicularia tenuissima f. campestris) [KöFARAgó-Gyelnik 1937, sub Cornicularia tenuissima f. campestris, FARKAS and LöKÖs 2007]. - Comit. Pest. In arenosis territ. "Lőportár dülő" infra opp. Vácz. Alt. s. m. met. ca. 100. Leg.: Boros, Á., 1920.03.25. (EGR sub Cetraria aculeata f. campestris) [Boros 1920]. - Comit. Pest. In arenosis territ. "Lőportár dülő" infra opp. Vácz. Alt. s. m. met. ca. 110. Leg.: Boros, Á., 1921.03.11. (BP 25423, BP 45383 sub Cetraria aculeata f. campestris) [BOROs 1921-22, VERSEGHY 1994, FARKAS and LöKös 2007]. - Comit. Pest. In arenosis territorii "Lőportár dülő" infra opp. Vácz. Alt. s. m. met. ca. 100. Leg.: Boros, Á., 1922.04.04. (EGR sub Cetraria aculeata f. campestris) [Boros 1921-22]. - Comit. Pest. In collibus arenosis versus rivum Tece prope Vácrátót. Alt. cca 130 m. Leg.: Boros, Á., 1949.08.27. (EGR, sub. Cornicularia (Cetraria) aculeata f. campestris) [Boros 1949]. - Comit. Pest. In collibus arenosis versus rivum Tece prope Vácrátót. Alt. cca 130 m. Leg.: Boros, Á., 1949.08.30. (EGR, sub Cornicularia (Cetraria) aculeata f. campestris) [Boros 1949]. - Vácrátót (C. Pest, Hungaria) versus Tece, in arenosis. Alt. cca 110 m. Leg.: Pénzes, A., 1949.08.30. (BP 85092, BP 85093 sub Cornicularia steppae) [Boros 1949, VERSEGHY 1994]. Com. Pest. Vácrátót. In colli arenoso. Leg.: Timár, L., 1949.08.31. (SZE, sub Cornicularia tenuissima f. campestris) [GAllé 1960]. - Comit. Pest, prope pagum Vácrátót. In colli arenoso. Leg.: Timár, L., 1949.08.31. (BP, sub Cornicularia tenuissima var. campestris) [GALLÉ 1960]. - Com. Pest. Vácrátót: in pratis. Substr.: terra arenaria. Alt.: $100 \mathrm{~m} \mathrm{s.} \mathrm{m.} \mathrm{Leg.:} \mathrm{Fóriss,} \mathrm{F.} \mathrm{(23870),} \mathrm{1948.09.02.}$ (BP 25420 sub Cornicularia tenuissima var. campestris, BP 55569 sub Cornicularis steppae, EGR sub Cornicularia steppae) [Verseghy 1994]. - Com. Pest. Vácrátót: in collis supra castellum. Substr.: solo arenaceo. Alt. $100 \mathrm{~m}$ s. m. Leg.: Fóriss, F. (23870), 1948.09.02. (JPU sub Cornicularia tenuissima var. campestris). - Comit. Pest. In collibus arenosis versus rivum Tece prope Vácrátót. Alt. cca 130 m s. m. Leg.: Boros, Á., 1949.10.01. (BP 45385, EGR sub Cornicularia aculeata f. campestris) [Boros 1949, Verseghy 1975, 1994]. - Vácrátót, homokos legelőn. Leg.: Pénzes, A., 1950.11.25. (VBI). - Comit. Pest. In arenosis versus Tece prope Vácrátót. Alt. cca $130 \mathrm{~m} \mathrm{s.} \mathrm{m.} \mathrm{Leg.:} \mathrm{Boros,} \mathrm{Á.,}$ 1950.12.02. (BP 48372, EGR sub Cornicularia aculeata f. campestris) [Boros 1950]. - Vácrátótkörnyéki mészkedvelő pusztagyep, Festucetum vaginatae danubiale. 14.09.-10.12.1952. [KÁRPÁTI and KÁRPÁti 1954a, sub Cornicularia tenuissima, VERSEGHY 1975]. - Vácrátót-Örszentmiklós, 1952; Vácrátót, Tece pasture alongside the Hosszúvölgy road, 1952.04.23; Vácrátót, Tece pasture beside the poultry farm, 1952.04.24; Vácrátót, Topolyos, 1952.06.10, 1952.12.10. [KÁRPÁTI and KÁRPÁTi 1954b, sub Cornicularia tenuissima, VERSEgHY 1975]. - Vácrátót, degradáltabb homokpuszta. [Zólyomi 1958, 1987, sub Cornicularia tenuissima]. - Along the Tece brook near the vil- 
lage Vácrátót (about $30 \mathrm{~km}$ NNE from Budapest), Festucetum vaginatae danubiale. [FEKETE et al. 1976, sub Cornicularia tenuissima]. - Vácrátót, Tece rét (védett terület), Festucetum vaginatae. 16.06.1976, 17.07.1977. [PRÉCSÉNYI and OPAUSZKY 1979, sub Cornicularia tenuissima]. - Vácrátót versus Tece, homok, 110 m s. m. Leg.: Farkas, E., 1982.11.02. (VBI 8203/A) [FARKAS and Lö Kös 2007]. - In Festucetum vaginatae danubiale on sandy soil of “Tece" area near Vácrátót, county Pest. Alt.: 110-120 m a. s. 1. Leg.: Farkas, E., 20.05.1984. (VBI/8422/A) [FARKAS and LöKös 2007]. - Comit. Pest. In collibus arenosis vallis rivi Egres prope Vácegres (Zsidó). Alt. cca $150 \mathrm{~m} \mathrm{s.} \mathrm{m.}$ Leg.: Boros, Á., 1962.06.22. (BP 55570, EGR sub Cornicularia tenuissima f. campestris) [Boros 1962, Verseghy 1994, FARKAS and LöKös 2007]. - Hungaria. Montes Cserhát. In collibus arenosis (Festucetum vaginatae) ad rivum Egres prope pag. Vácegres (Zsidó), comit. Pest. Alt. cca $150 \mathrm{~m} \mathrm{~s}$ mare. Leg.: Boros, Á., 1962.06.22. (EGR) [Boros 1962]. - Hungary. Gödöllői-dombság, Erdőkertes (Pest megye): Háromház, Erdőkertesi-homokpuszta, sand dunes. On sandy soil. Lat.: 47 39'52.3" N, Long.: $19^{\circ} 20^{\prime} 34.9^{\prime \prime}$ E, Alt.: ca 195 m a. s. l. Coll.: Farkas, E. and Lőkös, L., 04.05.2013. (BP 94569) (Fig. 3B).

Mecsek Mts - Mecsek, Kővágószőlős, Cserkút. Lat.: 46 04’ 15.02” N, Long.: 18 07’ 47.92” E, Alt.: ca 220 m a. s. 1. Coll.: Farkas, E., Lőkös, L. and Varga, N., 2013.05.18. (BP 94571) (Fig. 3A). - Mecsek, Kővágószőlős, Cserkút. Lat.: 46 04’ 02.47” N, Long.: 1807’ 26.45” E, Alt.: ca 190 m a. s. 1. Coll.: Farkas, E., Lőkös, L. and Varga, N., 2013.05.18. (BP 94572). - Mecsek, Kővágószőlős, Cserkút. Lat.: 460 04’ 01.39” N, Long.: 18 07’ 34.40” E, Alt.: ca 200 m a. s. 1. Coll.: Farkas, E., Lőkös, L. and Varga, N., 2013.05.18. (BP 94573). - Mecsek, Kővágószőlős, Cserkút. Lat.: 4604'03.39” N, Long.: 18 07’ 49.76" E, Alt.: ca 205 m a. s. l. Coll.: Farkas, E., Lőkös, L. and Varga, N., 2013.05.18. (BP 94574). - Mecsek, Kővágószőlős, Cserkút. Lat.: 460 04’ 10.24” N, Long.: 18 08’ 14.59” E, Alt.: ca 220 m a. s. 1. Coll.: Farkas, E., Lőkös, L. and Varga, N., 2013.05.18. (BP 94575). - Mecsek, Pécs, Sülevölgy, in acidophilous forests on acidic soil. Lat.: $46^{\circ} 04^{\prime} 48.56^{\prime \prime} \mathrm{N}$, Long.: $18^{\circ} 09^{\prime} 54.85^{\prime \prime}$ E, Alt.: ca 285 m a. s. 1. Coll.: Csiky, J., 28.03.2014. (BP 94576).

Vasi-Hegyhát - Ostffyasszonyfa mellett, autóút közelében, talajon, gyepben. Leg.: Farkas, E. and Lőkös, L., 1994. (BP) [FARKAS and LöKös 2007].

Velence Mts - Comit. Fejér. In collibus pr. pag. Nadap, ad terram inter muscos, alt. cca. 220 m s. m. Leg.: Fekete, G., 1953.09.19. (BP 48669 sub Cornicularia aculeata var. spadicea) [VERSEGHY 1994, FARKAS and LöKös 2007]. - Velencei-hegység: Csekély-hegy, Nadap mellett, Festucetum sulcatae-ban. [FEKETE 1954, sub Cornicularia tenuissima var. campestris]. - Velencei-hegység: Csehélyhegy, auf Quarzit, Festucetum sulcatae. Obs.: Fekete, G., 1953.09.19. [Fekete 1956, sub Cornicularia tenuissima]. - Velencei-hegység: Zwischen Kisfalud und Csala, auf Granit, Festucetum sulcatae. Obs.: Fekete, G., 1951-55. [FeKETE 1956, sub Cornicularia tenuissima]. - Velencei-hegység, Pákozd (Fejér megye): Zsellér-legelő, Telkes-mező. Alt.: ca $130 \mathrm{~m}$ a. s. 1. Coll.: Farkas, E. and Lőkös, L., 03.07.2004. (BP 94568) [FARKAS and LöKös 2007]. - Hungary. Velencei-hegység, Pázmánd (Fejér megye): $\mathrm{N}$ side of Mt Zsidó-hegy, open grassland with exposed boulders near the top. On acidic soil, among bryophytes. Lat.: $47^{\circ} 16^{\prime} 30.3^{\prime \prime} \mathrm{N}$, Long.: $18^{\circ} 39^{\prime} 38.4^{\prime \prime} \mathrm{E}$, Alt.: $180 \mathrm{~m}$ a. s. 1. Coll.: Farkas, E. and Lőkös, L., 05.05.2013. (BP 94567).

Acknowledgements - The research has been supported by the Hungarian Scientific Research Fund (OTKA K81232). We are indebted to the curators of the following Hungarian herbaria: EGR (Eszterházy Károly College, Eger), JPU (University of Pécs, Pécs), SZE (University of Szeged, Szeged) for the herbarium specimens. We are grateful to János Csiky (University of Pécs, Pécs), who drew our attention to the C. aculeata populations in the Mecsek Mts (Cserkút, Pécs: Sülevölgy) and also to the Hungarian Biodiversity Research Society for organising the 11th Hungarian Biodiversity Days at Cserkút in 2013. 


\section{REFERENCES}

Borhidi, A. (2003): Magyarország növénytársulásai. (Plant communities of Hungary). - Akadémiai Kiadó, Budapest, 612 pp.

Borhidi, A., Kevey, B. and Lendvai, G. (2012): Plant communities of Hungary. - Akadémiai Kiadó, Budapest, 544 pp.

Boros, Á. (1918, 1920, 1921-1922, 1949, 1950, 1962): Florisztikai jegyzetek. Vol. 4, 6, 7-8, 35, 36, 48. - Tudománytörténeti Gyüjtemény, Magyar Természettudományi Múzeum, Budapest, 159 pp., 119 pp., 187 pp., 199 pp., 213 pp., 324 pp. (mscr.)

Boros, Á. (1963): Die Steppenflechten. - Die Pyramide (Innsbruck) 11(2): 59-61.

Domasch Ke, S., Vivas, M., SAncho, L. G. and Printzen, C. (2013): Ecophysiology and genetic structure of polar versus temperate populations of the lichen Cetraria aculeata. - Oecologia 173(3): 699-709. http://dx.doi.org/10.1007/s00442-013-2670-3

Domaschke, S., Fernández-Mendoza, F., García, M. A., Martín, M. P. and Printzen, C. (2012): Low genetic diversity in Antarctic populations of the lichen-forming ascomycete Cetraria aculeata and its photobiont. - Polar Research 31(Suppl.): 17353. http://dx.doi.org/10.3402/polar.v31i0.17353

FARKAS, E. and Lőkös, L. (2004): A Cetraria aculeata zuzmófaj elterjedése Magyarországon. [Distribution of Cetraria aculeata in Hungary]. - Előadások és poszterek (összefoglaló kötet), Aktuális flóra- és vegetációkutatás a Kárpát-medencében VI, Keszthely, 2004. február 26-29, p. 46.

FARKAS, E. É. and Lőkös, L. (2005): Conservation of lichenised fungi in Hungary. - Program and Book of Abstracts, XVI Symposium of Mycologists and Lichenologists of Baltic States, Cesis, Latvia, p. 8.

FARKAS, E. and Lőkös, L. (2006): Törvényesen védett zuzmófajok Magyarországon. (Protected lichen species in Hungary). - Kitaibelia 11(1): 47.

FARKAS, E. and Lö Kös, L. (2007): Védett zuzmófajok Magyarországon. (Protected lichens in Hungary). - Mikol. Közlem., Clusiana 45(1-3): 159-171. (2006).

FArkas, E., Löкös, L. Sinigla, M. and VArga, N. (2014): A Mogyorós-hegy (Litér) és az Ugrihegy (Királyszentistván) zuzmóflórája. (The lichen flora of the hills "Mogyorós-hegy" (Litér, Hungary) and "Ugri-hegy" (Királyszentistván, Hungary)). - Folia Mus. Hist-nat. Bakony. 31: $7-24$.

Fekete, G. (1954): Chlorocyperus glaber (L.) Palla Magyarországon. - Bot. Közlem. 45(3-4): $253-254$.

Fenete, G. (1956): Die Vegetation des Velenceer Gebirges. - Annls hist.-nat. Mus. natn. Hung., Ser. nov. $7(2): 343-362$.

Fenete, G., Précsényi, I., Molnár, E. and Melkó, E. (1976): Niche studies on some plant species of a grassland community I. Comparison of various measurements. - Acta Bot. Acad. Sci. Hung. 22(3-4): 321-354.

Fernández-Mendoza, F., Domaschke, S., García, M. A., Jordan, P., Martín, M. P. and Printzen, C. (2011): Population structure of mycobionts and photobionts of the widespread lichen Cetraria aculeata. - Mol. Ecol. 20(6): 1208-1232. http://dx.doi.org/10.1111/j.1365-294X.2010.04993.x

FHE (Flora Hungarica Exsiccata) (1914): No. 215. Cetraria aculeata (Schreb.) E. Fries f. campestris Schaer. - Schedae ad Floram Hungaricam Exsiccatam, Cent. III, Fritz Ármin könyvnyomdája, Budapest, p. 9.

Gallé, L. (1960): Zuzmók Timár Lajos növénytani hagyatékából. (Flechten aus dem botanischen Nachlass von L. Timár). - Bot. Közlem. 48(3-4): 239-244. 
Gielwanows Ka, I. and Olech, M. (2012): New ultrastructural and physiological features of the thallus in Antarctic lichens. - Acta Biol. Cracoviensia, Ser. Bot. 54(1): 40-52. http://dx.doi.org/10.2478/v10182-012-0004-0

KäRNEFELT, I. (1986): The genera Bryocaulon, Coelocaulon and Cornicularia and formerly associated taxa. - Opera Botanica 86: 1-90.

KÁRPÁTI, I. and KÁRPÁTI, I.-né (1954a): A Vácrátót-környéki mészkedvelő pusztagyep (Festucetum vaginatae danubiale) 1952. évi aszpektusai. (Vizsgálati eredmények összefoglalása). (Aspects for 1952 of the calciphil Puszta turf in the surroundings of Vácrátót. - Bot. Közlem. 45(1-2): 109-114.

KÁRPÁTI, I. and KÁRPÁTI, I.-né (1954b): The aspects of the calciphilous turf(Festucetum vaginatae danubiale) in the environs of Vácrátót in 1952. - Acta Bot. Acad. Sci. Hung. 1(1-2): 129-157.

Köfaragó-Gyelnik, V. (1937): No. 195. Cornicularia tenuissima (L.) Zablbr.f.campestris (Schaer.) Lynge. - Lichenotheca, Fasc. 5-10, No. 81-200, Budapest.

Löкӧs, L. and Tóтн, Е. (1997): Red list of lichens of Hungary (a proposal). - In: Tóтн, E. and HoRváth, R. (eds): Proceedings of the "Research, Conservation, Management" Conference, Aggtelek, Hungary, 1-5 May 1996, Volume I, pp. 337-343.

MK (2005): 23/2005. (VIII. 31.) KvVM rendelet. A védett és a fokozottan védett növény- és állatfajokról, a fokozottan védett barlangok köréről, valamint az Európai Közösségben természetvédelmi szempontból jelentős növény- és állatfajok közzétételéről szóló 13/2001. (V. 9.) KöM rendelet módosításáról. - Magyar Közlöny 2005(117): 6371-6404. (2005. augusztus 31).

MK (2008): 18/2008. (VI. 19.) KvVM rendelet. A védett és a fokozottan védett növény- és állatfajokról, a fokozottan védett barlangok köréről, valamint az Európai Közösségben természetvédelmi szempontból jelentős növény- és állatfajok közzétételéről szóló 13/2001. (V. 9.) KöM rendelet módosításáról. - Magyar Közlöny 2008(90): 5435-5439. (2008. június 19).

MK (2013): 83/2013. (IX.25.) VM rendelet. A védett és a fokozottan védett növény- és állatfajokról, a fokozottan védett barlangok köréről, valamint az Európai Közösségben természetvédelmi szempontból jelentős növény- és állatfajok közzétételéről szóló 13/2001. (V. 9.) KöM rendelet módosításáról. - Magyar Közlöny 2013(156): 67479-67503. (2013. szeptember 25).

Nadyeina, O., LutsaK, T., Blum, O., Grakhov, V. and Scheidegger, C. (2013): Cetraria steppae Savicz is conspecific with Cetraria aculeata (Schreb.) Fr. according to morphology, secondary chemistry and ecology. - Lichenologist 45: 841-856. http://dx.doi.org/10.1017/S002428291300056X

Ni klfeld, H. (1971): Bericht über die Kartierung der Flora Mitteleuropas. - Taxon 20: 545-571.

Pérez-Ortega, S., Fernández-Mendoza, F., Raggio, J., Vivas, M., Ascaso, C., Sancho, L. G., Printzen, C. and De Los Ríos, A. (2012): Extreme phenotypic variation in Cetraria aculeata (lichenized Ascomycota): adaptation or incidental modification? - Ann. Bot. 109(6): 1133-1148. http://dx.doi.org/10.1093/aob/mcs042

PrÉCSÉNYI, I. and OPAUSZKY, I. (1979): Homokpusztai növények mikro- és ultramikroelem koncentrációja. (Micro and ultramicro element concentrations in some sand grassland plants). - Bot. Közlem. 66(1): 29-32.

Thiers, B. (2014, continuously updated): Index Herbariorum: a global directory of public herbaria and associated staff. - New York Botanical Garden's Virtual Herbarium. http://sweetgum.nybg.org/ih/.

Tıм Kó, Gy. (1925): Új adatok a Budai és Szentendre-Visegrádi hegyvidék zuzmóvegetációjának ismeretéhez. (Neue Beiträge zur Kenntnis der Flechtenvegetation des Buda-Szentendre-Visegráder Gebirges). - Bot. Közlem. 22: 81-104. (1924-25). 
Verseghy, K. (1975): Talajlakó xerofiton zuzmófajok ökológiája és elterjedése Magyarországon (II.) s néhány taxon revíziója. (Ökologie und Verbreitung der bodenbewohnenden xerophytischen Flechtenarten in Ungarn (II), und Revision einiger Taxonen). - Studia bot. hung. 10: 41-61.

VERSEGHY, K. (1994): Magyarország zuzmóflórájának kézikönyve. [The lichen flora of Hungary]. Magyar Természettudományi Múzeum, Budapest, 415 pp.

Zólyomi, B. (1958): Budapest és környékének természetes növénytakarója. - In: PÉcsi, M., MAROsI, S. and SzILÁRD, J. (eds): Budapest természeti képe. Akadémiai Kiadó, Budapest, pp. 511-644.

Zólyomi, B. (1987): Buntflechten-Moos und Lebenmoos Synusien. - Symposia Biol. Hung. 35: 375-378. 